\title{
ASUPAN NATRIUM DAN TEKANAN DARAH SEBAGAI FAKTOR RISIKO PENINGKATAN KADAR C-REACTIVE PROTEIN (CRP) PADA REMAJA OBESITAS DENGAN SINDROM METABOLIK
}

\author{
Evi Nurhayati Desrini, Muhammad Sulchan*) \\ Program Studi Ilmu Gizi Fakultas Kedokteran Universitas Diponegoro \\ J1.Dr.Sutomo No.18, Semarang, Telp (024) 8453708, Email : gizifk@ undip.ac.id
}

\begin{abstract}
Background: The metabolic syndrome has found not only in adult but also in adolescent. The prevalence of the metabolic syndrome in adolescent increased with the severity of obesity. Metabolic syndrome can be defined by the increasing of CRP level. Sodium intake and blood pressure are risk factor for metabolic syndrome. The purpose of this study is to find out the risk of sodium intake and blood pressure to the increased CRP level in adolescent.

Method: A cross-sectional study was conducted in SMA Negeri 2 Semarang consist of 38 students as the subjects. Data sodium intake has obtained by interview using Food Frequency Questionnaire last one month. Blood pressure has checked using Sphygmomanometer. CRP level has checked with aglutination. Height measurements using microtoise, weight using digital scales, waist circumferences using a tape measure. Ratio prevalence was used to analyze the risk of high sodium intake and high blood pressure to the increased CRP level.

Result: The prevalence of metabolic syndrome is 15,2\%. In this study has found 8 (80\%) subjects with the metabolic syndrome has a high blood pressure and $10(100 \%)$ subjects with metabolic syndrome has a high sodium intake. There were unsignificantly risk between high sodium intake $(R P=1,031, C I 95 \%=0,165-6,646)$ and high systolic blood pressure $(R P=0,369, C I 95 \%=0,028-2,471)$ to the increased CRP levels.

Conclusion: In this study, high sodium intake and high systolic blood pressure are not proved can increasing CRP level. High sodium intake has 1,048 greater risk to the increased CRP level.

Key words: adolescents, metabolic syndrome, sodium intake, blood pressure, C-Reactive Protein
\end{abstract}

\begin{abstract}
ABSTRAK
Latar belakang: Sindrom metabolik tidak hanya terjadi pada orang dewasa, tetapi juga ditemukan pada remaja. Prevalensi sindrom metabolik pada remaja terus meningkat seiring dengan keparahan obesitas yang terjadi. Sindrom metabolik ditandai dengan peningkatan kadar CRP darah. Asupan natrium dan tekanan darah merupakan faktor risiko sindrom metabolik. Penelitian ini bertujuan untuk mengetahui besar risiko asupan natrium dan tekanan darah terhadap peningkatan kadar CRP pada remaja.

Metode: Penelitian dilakukan di SMA Negeri 2 Semarang. Desain penelitian cross sectional dengan jumlah subyek 38 siswa yang memenuhi kriteria inklusi. Data asupan natrium didapatkan dari wawancara menggunakan Food Frequency Questionnaire satu bulan terakhir. Tekanan darah diperiksa dengan Sphygmomanometer. Kadar CRP diperiksa dengan teknik aglutinasi. Pengukuran tinggi badan menggunakan microtoise, berat badan menggunakan timbangan digital, dan lingkar pinggang menggunakan pita ukur. Data dianalisis dengan uji statistik rasio prevalensi untuk mengetahui besar risiko asupan natrium tinggi dan tekanan darah tinggi terhadap peningkatan kadar CRP.

Hasil: Prevalensi sindrom metabolik pada remaja obesitas sebesar 15,2\%. Penelitian ini menemukan 8 (80 \%) subyek dengan sindrom metabolik memiliki tekanan darah tinggi dan 10 (100\%) subyek dengan sindrom metabolik memiliki asupan natrium tinggi. Didapatkan besar risiko yang tidak bermakna antara asupan natrium tinggi $(R P=1,031, C I 95 \%=0,165-6,646)$ dan tekanan darah sistolik tinggi $(R P=0,369, C I 95 \%=0,028-2,471)$ terhadap peningkatan kadar CRP.
\end{abstract}

Simpulan: Pada penelitian ini asupan natrium tinggi dan tekanan darah sistolik tinggi tidak terbukti dapat meningkatkan kadar CRP. Asupan natrium tinggi memberikan risiko 1,048 kali terhadap peningkatan kadar CRP.

Kata kunci: remaja, sindrom metabolik, asupan natrium, tekanan darah, C-Reactive Protein

\section{PENDAHULUAN}

Sindrom metabolik merupakan istilah untuk kelompok faktor risiko penyakit jantung dan diabetes mellitus. Ada dua penyebab utama kejadian sindrom metabolik yang saling berinteraksi, yaitu obesitas dan kerentanan metabolisme endogenus. ${ }^{1}$ Angka kejadian sindrom metabolik meningkat seiring dengan meningkatnya kejadian obesitas sentral atau obesitas viseral. Lemak viseral secara metabolik lebih aktif daripada lemak perifer. $^{2}$

Sindrom metabolik kronis biasa ditemui pada usia dewasa, namun, pada beberapa penelitian ditemukan kejadian sindrom metabolik pada usia

${ }^{*}$ Penulis Penanggungjawab 
remaja. Prevalensi kejadian sindrom metabolik pada remaja meningkat seiring dengan meningkatnya keparahan obesitas yang terjadi. ${ }^{3}$ Laporan dari National Cholesterol Education Program Adult Treatment Panel III (NCEP-ATP III) menunjukkan peningkatan prevalensi sindrom metabolik pada remaja dari periode 1988-1992 ke periode 1999-2000, yaitu dari 4,2\% menjadi 6,4 $\%$. Prevalensi laki-laki yang mengalami sindrom metabolik lebih besar dibanding perempuan, yaitu $9,1 \%$ dibanding 3,7\%. Remaja dengan Indeks Masa Tubuh (IMT) persentil ke 95 sebesar 32,1\% mengalami sindrom metabolik, sedangkan remaja yang memiliki IMT antara persentil ke 85-95 didapatkan angka kejadian sindrom metabolik sebesar $7 \% .^{4}$

Peningkatan angka kejadian obesitas tiap tahunnya merupakan produk dari perubahan pola hidup masyarakat dunia, dimana hal ini berperan pula dalam perubahan pola makan remaja, kejadian obesitas juga disebabkan oleh kurangnya aktivitas fisik. ${ }^{5}$ Obesitas yang terjadi pada masa remaja, 30 $\%$ akan berlanjut sampai dewasa menjadi obesitas persisten. Obesitas yang terjadi pada masa remaja bila terus berlanjut hingga dewasa akan sulit untuk ditangani dengan pengaturan diet dan olahraga, sehingga obesitas pada masa remaja perlu mendapatkan perhatian khusus.

Pemilihan makan pada remaja merupakan faktor penting yang melatarbelakangi kejadian obesitas remaja selain faktor aktivitas fisik. Remaja kini cenderung memilih makanan dengan ciri tinggi kandungan karbohidrat, tinggi kalori, tinggi lemak dan tinggi natrium. ${ }^{6,7}$ Obesitas dan tingginya asupan natrium yang disebabkan oleh pola makan yang salah merupakan faktor risiko hipertensi pada remaja. Estimasi risiko dari Framingham Heart Study menunjukkan bahwa 78 $\%$ hipertensi pada laki-laki dan $65 \%$ hipertensi pada wanita secara langsung berhubungan dengan obesitas. Risiko kejadian hipertensi meningkat sampai 2,6 kali pada subjek laki-laki obesitas dan meningkat 2,2 kali pada subjek wanita obesitas dibanding subjek dengan berat badan normal. ${ }^{8}$ Konsumsi natrium yang berlebihan dalam jangka waktu lama juga berpotensi besar untuk meningkatkan tekanan darah atau hipertensi. Anjuran konsumsi natrium untuk remaja adalah 1500-2300 mg/hari agar dampak kelebihan konsumsi natrium dapat dihindari. Pola konsumsi natrium yang berlebihan pada saat anak-anak dan remaja dapat menyebabkan terjadinya hipertensi pada saat dewasa dan lanjut usia. ${ }^{9}$
Tekanan darah tinggi atau hipertensi merupakan salah satu komponen diagnosis sindrom metabolik yang berkaitan dengan peningkatan kadar $C$-Reactive Protein (CRP). $C$ Reactive Protein (CRP) adalah suatu penanda sensitif terjadinya proses inflamasi sistemik di dalam tubuh yang diproduksi oleh hepar. Adanya peningkatan tekanan darah disebut sebagai salah satu faktor risiko peningkatan kadar CRP. ${ }^{10}$ Remaja dengan sindrom metabolik mengalami peningkatan kadar CRP yang diketahui meningkatkan risiko terjadinya penyakit kardiovaskuler pada saat dewasa. Namun, penelitian yang membahas asupan makan, komponen sindrom metabolik, serta biomarker inflamasi pada remaja obesitas masih terbatas.

\section{METODE PENELITIAN}

Penelitian ini termasuk dalam ruang lingkup penelitian gizi masyarakat dengan rancangan penelitian cross sectional. ${ }^{11}$ Populasi target dalam penelitian ini adalah semua remaja usia 15-18 tahun di Kota Semarang. Populasi terjangkau pada penelitian ini adalah semua siswa 15-18 tahun di SMA Negeri 2 Semarang. Besar sampel dihitung dengan menggunakan rumus perhitungan besar sampel dan didapatkan besar sampel adalah 38 orang. Pengambilan sampel dilakukan dengan cara Simple Random Sampling. Kriteria inklusi yang digunakan adalah subyek berusia 15-18 tahun, termasuk ke dalam kriteria pra sindrom metabolik, yaitu mengalami obesitas sentral, tidak sedang mengonsumsi obat-obatan untuk obesitas, hipertensi, dan hipoglikemi, dan tidak dalam keadaan sakit atau dalam perawatan dokter berkaitan dengan penyakit kronik. Kriteria eksklusi adalah subyek yang mengundurkan diri, subyek yang sakit, serta subyek yang meninggal saat penelitian berlangsung. Dari hasil skrining ditemukan 47 subyek termasuk dalam kriteria pra sindrom metabolik, yang dijadikan sebagai dasar untuk melihat prevalensi faktor risiko sindrom metabolik. Namun, hanya 38 subyek yang dilakukan pemeriksaan kadar $C$-Reactive Protein lebih lanjut.

Variabel terikat dalam penelitian ini adalah kadar C-Reactive Protein (CRP), sedangkan variabel bebas adalah asupan natrium dan tekanan darah.

Pemilihan subyek penelitian, pengambilan sampel darah, serta wawancara asupan makan dilakukan pada bulan Mei 2014. Pemeriksaan yang dilakukan meliputi pengukuran antropometri, pengukuran tekanan darah, dan pengambilan sampel darah 
untuk memeriksa parameter komponen sindrom metabolik. Pengukuran antropometri subyek dilakukan untuk menentukan status gizi berdasarkan BMI for age percentile. Pengukuran berat badan menggunakan timbangan berat badan dengan ketelitian $0,1 \mathrm{~kg}$. Pengukuran tinggi badan menggunakan microtoise dengan ketelitian $0,1 \mathrm{~cm}$. Pengukuran lingkar pinggang menggunakan pita ukur/metlin dengan panjang maksimal $150 \mathrm{~cm}$. Pengukuran tekanan darah dilakukan oleh tenaga ahli menggunakan Sphygmomanometer air raksa dengan metode tidak langsung (indirect methode) dengan cara auskultasi.

Penentuan keadaan sindrom metabolik merujuk pada kriteria National Cholesterol Education Program's Adult Treatment Panel (NCEP-ATP III). Berdasarkan pada kriteria NCEPATP III, dapat dikatakan sebagai sindrom metabolik ketika ditemukan setidaknya tiga dari kriteria berikut: (1) Obesitas abdominal $>102 \mathrm{~cm}$ untuk pria; atau $>88 \mathrm{~cm}$ untuk wanita. Batasan lingkar pinggang untuk menentukan obesitas abdominal pada remaja adalah bila $\geq$ persentil 90 , dimana nilainya adalah $93 \mathrm{~cm}$ untuk remaja lakilaki dan $87 \mathrm{~cm}$ untuk remaja (2) kadar serum trigliserida $\geq 150 \mathrm{mg} / \mathrm{dL}$ (3) kadar HDL kolesterol $<40 \mathrm{mg} / \mathrm{dL}$ untuk pria; atau $<50 \mathrm{mg} / \mathrm{dL}$ untuk wanita (4) Tekanan darah $\geq 130 / 85 \mathrm{mmHg}$. Batasan tekanan darah pada remaja digunakan nilai $\geq$ persentil 90, dimana nilai untuk tekanan darah sistolik dikatakan tinggi bila di atas $122 \mathrm{mmHg}$ dan nilai untuk tekanan darah diastolik dikatakan tinggi bila di atas $77 \mathrm{mmHg}$ (5) kadar gula darah puasa $\geq 110 \mathrm{mg} / \mathrm{dL}$.

Asupan natrium adalah rata-rata asupan natrium dari makanan yang dikonsumsi oleh responden dalam waktu satu hari yang diperoleh secara langsung dengan menggunakan Food Frequency Questionare (FFQ), kemudian dikonversikan ke dalam satuan $\mathrm{mg} / \mathrm{hari}$. Asupan natrium dikatakan tinggi bila $>2300 \mathrm{mg} / \mathrm{hari}$ atau setara dengan 6 gram natrium klorida (garam dapur). Kadar C-Reactive Protein (CRP) adalah kadar CRP dalam plasma darah responden yang menggambarkan adanya proses inflamasi sistemik yang diproduksi oleh hepar. ${ }^{12}$ kadar CRP diperiksa dengan teknik aglutinasi, dikatakan tinggi apabila nilainya $>6 \mathrm{mg} / \mathrm{L}$.

Pengolahan dan analisis data menggunakan program komputer. Analisis univariat untuk mengetahui karakteristik subyek penelitian. Analisis bivariat menggunakan uji pearson atau spearman untuk melihat hubungan asupan natrium dengan faktor risiko sindrom metabolik serta kadar CRP dengan tekanan darah. Sedangkan untuk mengetahui faktor risiko asupan natrium dan tekanan darah terhadap kadar CRP digunakan uji statistik Ratio Prevalence (RP).

\section{HASIL}

Hasil skrining awal yang diikuti 835 remaja berasal dari SMA Negeri 2 Semarang menunjukkan sebanyak $80 \quad(9,58 \quad \%)$ siswa mengalami overweight, $66 \quad(7,9 \quad \%)$ siswa mengalami obesitas, $61(7,3 \%)$ siswa di antaranya termasuk dalam obesitas sentral, dan $10(1,1 \%)$ siswa mengalami sindrom metabolik. Prevalensi pra sindrom metabolik pada siswa obesitas adalah 94,2 \% dan prevalensi sindrom metabolik pada siswa obesitas adalah $15,2 \%$. Tabel 1 . menunjukkan status gizi dan hasil pemeriksaan laboratorium terhadap komponen sindrom metabolik pada subyek.

Tabel 1. Status Gizi dan Faktor Risiko Sindrom Metabolik pada Subyek

\begin{tabular}{lcc}
\hline \multicolumn{1}{c}{ Variabel } & $\begin{array}{c}\text { Kelompok Sindrom } \\
\text { Metabolik }\end{array}$ & $\begin{array}{c}\text { Kelompok Pra Sindrom } \\
\text { Metabolik }\end{array}$ \\
\hline Total & $16,5(15-17)$ & $16(15-17)$ \\
Usia & $32,5(29,6-45,6)$ & $30,3(25,9-43,3)$ \\
IMT & $105(97,5-120,3)$ & $93,5(87-134)$ \\
Lingkar Pinggang & $130(120-140)$ & $110(100-140)$ \\
TD Sistol & $70(70-80)$ & $70(70-80)$ \\
TD Diastol & $79,9 \pm 10,9$ & $82,2 \pm 6,2$ \\
GDP & $119(72-181)$ & $72(50-135)$ \\
Trigliserida & $32,5(30-48)$ & $42(30-56)$ \\
Kolesterol HDL & $16,5(15-17)$ & $16(15-17)$ \\
\hline Laki-laki & $32,6(29,6-45,6)$ & $30,3(25,9-43,3)$ \\
Usia & $105,9 \pm 8,1$ & $101,4 \pm 10,3$ \\
IMT & $130(120-140)$ & $120(110-140)$ \\
Lingkar Pinggang & & \\
TD Sistol & &
\end{tabular}


Catatan :

\begin{tabular}{lcc}
\hline TD Diastol & $70(70-80)$ & $70(70-80)$ \\
GDP & $79,9 \pm 10,9$ & $83,6 \pm 5,6$ \\
Trigliserida & $117,2 \pm 32,5$ & $76,5 \pm 15,2$ \\
Kolesterol HDL & $32,5(30-48)$ & $40(30-56)$ \\
\hline Perempuan & & $16(15-17)$ \\
Usia & - & $31,4 \pm 2,8$ \\
IMT & - & $90(87-114,4)$ \\
Lingkar Pinggang & - & $110(100-120)$ \\
TD Sistol & - & $70(70-70)$ \\
TD Diastol & - & $81 \pm 6,6$ \\
GDP & - & $51(50-135)$ \\
Trigliserida & - & $44,1 \pm 6,1$ \\
Kolesterol HDL & - & \\
\hline
\end{tabular}

IMT Indeks Massa Tubuh, LP Lingkar Pinggang, TDS Tekanan Darah Sistolik, TDD Tekanan Darah Diastolik, GDP Gula Darah Puasa, $T G$ Trigliserida, HDL High Density Lipoprotein.

Tabel 1. menunjukkan dari total subyek, kelompok sindrom metabolik memiliki nilai median yang lebih tinggi dibandingkan dengan kelompok pra sindrom metabolik pada hampir semua variabel yaitu pada usia, IMT, lingkar pinggang, tekanan darah sistolik dan trigliserida. Pada variabel tekanan darah diastolik memiliki nilai median yang sama antara kelompok pra sindrom metabolik dengan kelompok sindrom metabolik. Sedangkan pada variabel gula darah puasa dan kolesterol HDL memiliki nilai rerata dan nilai median yang lebih tinggi pada kelompok pra sindrom metabolik dibandingkan dengan kelompok sindrom metabolik.

Nilai median pada subyek laki-laki memiliki gambaran yang hampir sama dengan gambaran pada total subyek dimana median dan nilai rerata pada kelompok sindrom metabolik lebih tinggi dibandingkan dengan kelompok pra sindrom metabolik pada variabel usia, IMT, lingkar pinggang, tekanan darah sistolik, dan trigliserida. Nilai median pada variabel tekanan darah diastolik adalah sama antara kelompok pra sindrom metabolik dengan kelompok sindrom metabolik. Sedangkan pada variabel gula darah puasa dan variabel kolesterol HDL memiliki nilai rerata dan nilai median yang lebih tinggi pada kelompok pra sindrom metabolik dibandingkan dengan kelompok sindrom metabolik.

Pada subyek perempuan, tidak ada subyek yang termasuk dalam kelompok sindrom metabolik sehingga nilai rerata dan nilai median hanya muncul pada kelompok pra sindrom metabolik.

Tabel 2. Frekuensi Faktor Risiko Sindrom Metabolik pada Subyek

\begin{tabular}{|c|c|c|c|c|}
\hline \multirow{2}{*}{$\begin{array}{ll} & \text { Komponen } \\
\text { Total } & \end{array}$} & \multicolumn{2}{|c|}{$\begin{array}{c}\text { Sindrom } \\
\text { Metabolik }(n=10) \\
\end{array}$} & \multicolumn{2}{|c|}{$\begin{array}{c}\text { Pra Sindrom } \\
\text { Metabolik }(n=37)\end{array}$} \\
\hline & & & & \\
\hline LP (obesitas sentral) & 10 & $100 \%$ & 37 & $100 \%$ \\
\hline $\mathrm{TDS} \geq 122 \mathrm{mmHg}$ & 8 & $80 \%$ & 2 & $7,1 \%$ \\
\hline $\mathrm{TDD} \geq 77 \mathrm{mmHg}$ & 4 & $40 \%$ & 1 & $2,7 \%$ \\
\hline $\mathrm{GDP} \geq 100 \mathrm{mg} / \mathrm{dL}$ & - & - & - & - \\
\hline Trigliserida $\geq 110 \mathrm{mg} / \mathrm{Dl}$ & 6 & $60 \%$ & 3 & $8,1 \%$ \\
\hline $\mathrm{HDL}<40 \mathrm{mg} / \mathrm{dL}$ & 9 & $90 \%$ & 13 & $35,1 \%$ \\
\hline \multicolumn{5}{|l|}{ Laki-laki } \\
\hline $\mathrm{LP}>93$ & 10 & $100 \%$ & 18 & $100 \%$ \\
\hline $\mathrm{TDS} \geq 122 \mathrm{mmHg}$ & 8 & $80 \%$ & 2 & $11,1 \%$ \\
\hline $\mathrm{TDD} \geq 77 \mathrm{mmHg}$ & 4 & $40 \%$ & 1 & $5,6 \%$ \\
\hline $\mathrm{GDP} \geq 100 \mathrm{mg} / \mathrm{dL}$ & - & - & - & - \\
\hline Trigliserida $\geq 110 \mathrm{mg} / \mathrm{dL}$ & 6 & $60 \%$ & - & - \\
\hline $\mathrm{HDL}<40 \mathrm{mg} / \mathrm{dL}$ & 9 & $90 \%$ & 9 & $50 \%$ \\
\hline \multicolumn{5}{|l|}{ Perempuan } \\
\hline $\mathrm{LP}>87$ & - & - & 19 & $100 \%$ \\
\hline $\mathrm{TDS} \geq 122 \mathrm{mmHg}$ & - & - & - & - \\
\hline
\end{tabular}


Catatan :

\begin{tabular}{|c|c|c|c|c|}
\hline $\mathrm{TDD} \geq 77 \mathrm{mmHg}$ & - & - & - & - \\
\hline $\mathrm{GDP} \geq 100 \mathrm{mg} / \mathrm{dL}$ & - & - & - & - \\
\hline Trigliserida $\geq 110 \mathrm{mg} / \mathrm{dL}$ & - & - & 3 & $15,8 \%$ \\
\hline $\mathrm{HDL}<40 \mathrm{mg} / \mathrm{dL}$ & - & - & 4 & $21,1 \%$ \\
\hline
\end{tabular}

IMT Indeks Massa Tubuh, LP Lingkar Pinggang, TDS Tekanan Darah Sistolik, TDD Tekanan Darah Diastolik, GDP Gula Darah Puasa, $T G$ Trigliserida, $H D L$ High Density Lipoprotein.

Tabel 2. menunjukkan frekuensi yang paling tinggi muncul sebagai faktor risiko sindrom metabolik pada total subyek secara berturut-turut adalah lingkar pinggang dengan keseluruhan subyek memiliki nilai lingkar pinggang di atas nilai normal, kemudian diikuti dengan kolesterol HDL, tekanan darah sistolik, trigliserida, tekanan darah diastolik, dan terakhir adalah gula darah puasa dimana tidak terdapat subyek dengan nilai gula darah puasa yang abnormal. Untuk kelompok pra sindrom metabolik, frekuensi yang paling tinggi muncul secara berturut-turut adalah lingkar pinggang, kolesterol HDL, trigliserida, tekanan darah sistolik, tekanan darah diastolik, dan terakhir gula darah puasa.

Gambaran frekuensi kemunculan faktor risiko sindrom metabolik pada subyek laki-laki sama dengan gambaran frekuensi pada keseluruhan total subyek dikarenakan semua subyek yang termasuk sindrom metabolik adalah subyek lakilaki. Frekuensi kemunculan faktor risiko pada kelompok pra sindrom metabolik subyek laki-laki secara berturut-turut adalah lingkar pinggang, kolesterol HDL, tekanan darah sistolik, dan tekanan darah diastolik, kemudian tidak ada subyek dengan kadar trigliserida dan gula darah puasa di atas normal.

Pada subyek perempuan hanya terdapat kelompok pra sindrom metabolik dimana frekuensi kemunculan faktor risiko pada kelompok pra sindrom metabolik secara berturut-turut dari nilai tertinggi adalah lingkar pinggang, kolesterol HDL, dan trigliserida, tidak terdapat subyek dengan nilai tekanan darah sistolik, tekanan darah diastolik, dan gula darah puasa di atas nilai normal.

Tabel 3. Frekuensi Subyek Berdasarkan Kadar CRP

\begin{tabular}{lcccc}
\hline \multirow{2}{*}{ Karakteristik } & \multicolumn{2}{c}{ Kadar CRP Rendah } & \multicolumn{2}{c}{ Kadar CRP Tinggi } \\
\cline { 2 - 5 } & $\mathbf{N}$ & $\mathbf{\%}$ & $\mathbf{N}$ & \% \\
\hline Jenis kelamin & 18 & $72 \%$ & 6 & $46,2 \%$ \\
$\quad$ Laki-laki & 7 & $28 \%$ & 7 & $53,8 \%$ \\
$\quad$ Perempuan & & & & \\
Usia & 6 & $24 \%$ & 6 & $46,2 \%$ \\
15 tahun & 11 & $44 \%$ & 5 & $38,5 \%$ \\
16 tahun & 8 & $32 \%$ & 2 & $15,4 \%$ \\
17 tahun & & &
\end{tabular}

Tabel 3. menunjukkan frekuensi subyek berdasarkan kadar CRP. Pada kelompok kadar CRP rendah, frekuensi subyek tertinggi berdasarkan jenis kelamin adalah pada laki-laki dengan jumlah 18 anak (72\%), sedangkan pada kelompok kadar CRP tinggi frekuensi subyek tertinggi adalah pada perempuan dengan jumlah 7 anak $(53,8 \%)$. Pada kelompok kadar CRP rendah, frekuensi subyek tertinggi berdasarkan usia adalah pada usia 16 tahun dengan jumlah subyek sebanyak 11 anak (44 \%), sedangkan pada kelompok kadar CRP tinggi frekuensi subyek tertinggi adalah pada usia 15 tahun dengan jumlah subyek sebanyak 6 anak (46,2\%).

Hubungan Asupan Natrium dengan Faktor Risiko Sindrom Metabolik dan Kadar CRP

Tabel 4. Hubungan Asupan Natrium dengan Faktor Risiko Sindrom Metabolik dan Kadar CRP

\begin{tabular}{lcc}
\hline \multirow{1}{*}{ Variabel } & \multicolumn{2}{c}{ Asupan Natrium } \\
\cline { 2 - 3 } & 0,146 & $\boldsymbol{p}$ \\
\hline Lingkar Pinggang (cm) $^{\mathrm{NS}}$ & 0,358 & 0,383 \\
TD Sistolik (mmHg)* $_{\text {TD Diastolik (mmHg)** }}$ & 0,493 & 0,027 \\
GDP (mg/dL) $^{\mathrm{NS}}$ & $-0,015$ & 0,002 \\
Trigliserida (mg/dL)* & 0,324 & 0,930 \\
Kolesterol HDL (mg/dL) $^{\mathrm{NS}}$ & $-0,084$ & 0,047 \\
CRP (mg/dL) & 0,052 & 0,618 \\
\hline
\end{tabular}


$\begin{aligned} \text { Catatan: } & * \mathrm{p}<0,05 \\ * * \mathrm{p}<0,01 & \text { NS Not Significant }\end{aligned}$

Tabel 4. menunjukkan hubungan asupan natrium dengan faktor risiko sindrom metabolik dan kadar CRP. Asupan natrium memiliki korelasi yang bermakna dengan variabel tekanan darah sistolik $(\mathrm{p}<0,05)$, variabel tekanan darah diastolik $(\mathrm{p}<0,01)$, dan variabel trigliserida $(\mathrm{p}<0,05)$.
Hampir seluruh variabel memiliki arah korelasi positif kecuali variabel gula darah puasa dan variabel kolesterol HDL, namun kedua variabel ini memiliki korelasi yang lemah dan tidak bermakna.

Hubungan Asupan Natrium dan Faktor Risiko Tekanan Darah dengan Kadar CRP Tinggi

Tabel 5. Hubungan Asupan Natrium dan Faktor Risiko Tekanan Darah dengan Kadar CRP

\begin{tabular}{lcc}
\hline \multicolumn{1}{c}{ Variabel } & \multicolumn{2}{c}{ Kadar CRP Tinggi } \\
\cline { 2 - 3 } & $\mathbf{r}$ & $\boldsymbol{p}$ \\
\hline Asupan Natrium (mg/hari) & 0,247 & 0,415 \\
TD Sistolik $(\mathrm{mmHg})^{\mathrm{NS}}$ & 0,070 & 0,820 \\
TD Diastolik $(\mathrm{mmHg})^{\mathrm{NS}}$ & $-0,154$ & 0,615 \\
\hline
\end{tabular}

Catatan: * $\mathrm{p}<0,05 \quad$ NS Not Significant

Tabel 5. menunjukkan hubungan asupan natrium dan faktor risiko tekanan darah dengan kadar CRP. Kadar CRP memiliki korelasi yang tidak bermakna dengan asupan natrium dan tekanan darah diastolik ( $\mathrm{p}>0,05)$.

Hubungan Asupan Natrium dan Tekanan Darah dengan Kadar CRP

Tabel 6. Hubungan Asupan Natrium dan Tekanan Darah dengan Kadar CRP

\begin{tabular}{|c|c|c|c|c|c|c|c|}
\hline & \multicolumn{2}{|c|}{ Kadar CRP Tinggi } & \multicolumn{2}{|c|}{ Kadar CRP Rendah } & \multirow[t]{2}{*}{$p$} & \multirow[t]{2}{*}{$\mathbf{R P}$} & \multirow[t]{2}{*}{$95 \% \mathrm{CI}$} \\
\hline & $\mathrm{N}$ & $\%$ & $\mathrm{~N}$ & $\%$ & & & \\
\hline Asupan Natrium & & & & & & & \\
\hline Tidak Sesuai & 11 & 28,9 & 21 & 55,2 & 1,000 & 1,031 & $0,165-6,646$ \\
\hline Sesuai & 2 & 5,3 & 4 & 10,5 & & & \\
\hline $\begin{array}{l}\text { Tekanan Darah } \\
\text { Sistolik }\end{array}$ & & & & & & & \\
\hline$\geq 122$ & 1 & 2,6 & 6 & 15,8 & 0,385 & 0,369 & $0,028-2,471$ \\
\hline$<122$ & 12 & 31,6 & 19 & 50 & & & \\
\hline
\end{tabular}

Tabel 6. menunjukkan hubungan asupan natrium dan tekanan darah dengan kadar CRP. Pada kelompok dengan kadar CRP tinggi terdapat 11 subyek $(28,9 \%)$ yang asupan natriumnya tidak sesuai dengan kebutuhan dan 2 subyek $(5,3 \%)$ yang asupan natriumnya sesuai dengan kebutuhan. Pada kelompok dengan kadar CRP rendah terdapat 21 subyek $(55,2 \%)$ yang asupan natriumnya tidak sesuai dengan kebutuhan dan 4 subyek $(10,5 \%)$ yang asupan natriumnya sesuai dengan kebutuhan. Asupan natrium memiliki nilai RP sebesar 1,031 dengan CI $95 \%$ 0,165-6,646 yang berarti asupan natrium yang tidak sesuai berisiko 1,03 kali untuk berkembang menjadi kadar CRP tinggi dibandingkan dengan asupan natrium yang sesuai.

Pada kelompok dengan kadar CRP tinggi terdapat 1 subyek $(2,6 \%)$ yang memiliki tekanan darah sistolik tinggi dan 12 subyek $(31,6 \%)$ yang memiliki tekanan darah sistolik normal. Pada kelompok dengan kadar CRP rendah terdapat 6 subyek $(15,8 \%)$ yang memiliki tekanan darah sistolik tinggi dan 19 subyek (50\%) yang memiliki tekanan darah sistolik normal. Tekanan darah sistolik memiliki nilai $R P$ sebesar 0,369 dengan $C I$ $95 \%$ 0,028-2,471yang berarti tekanan darah sistolik yang tinggi berisiko 0,3 kali untuk berkembang menjadi kadar CRP tinggi dibandingkan dengan tekanan darah sistolik yang normal.

Hubungan tekanan darah diastolik dengan kadar CRP tidak dapat dianalisis karena tekanan darah diastolik seluruh subyek termasuk dalam kategori normal.

\section{PEMBAHASAN}

Prevalensi obesitas pada orang dewasa maupun anak-anak dan remaja di seluruh dunia mengalami peningkatan secara progresif baik pada negara berkembang maupun negara maju. ${ }^{13}$ Penelitian yang dilakukan pada remaja usia 15-17 tahun di SMA Negeri 2 Semarang diketahui prevalensi obesitas sebesar 7,3\%. Angka ini lebih rendah dibandingkan dengan penelitian yang dilakukan pada siswa SMP swasta di Semarang 
tahun 2005 yang menyebutkan prevalensi obesitas sebesar 17,6 \%. ${ }^{14}$ Kemudian penelitian ini juga menemukan prevalensi pra sindrom metabolik pada remaja obesitas sebesar 94,2 \% dan prevalensi sindrom metabolik pada remaja obesitas sebesar 15,2 \%. Angka tersebut lebih rendah dibandingkan dengan penelitian serupa pada siswa SMP Domenico Savio di Semarang tahun 2005 yang menemukan prevalensi sindrom metabolik sebesar $31,6 \%$ pada remaja obesitas. ${ }^{14}$ Perbedaan angka tersebut, kemungkinan dipengaruhi oleh karakteristik subyek penelitian di kedua tempat penelitian dimana pada remaja SMA Negeri 2 memiliki latar belakang sosial ekonomi yang merata dari berbagai kalangan, hal ini dapat dilihat dari letak sekolah yang berada di pertengahan kota serta serta jenis kendaraan yang digunakan para siswa untuk berangkat ke sekolah sebagian besarnya adalah sepeda motor dan angkutan umum. Berbeda dengan subyek penelitian di SMP Domenico Savio dimana rata-rata subyek memiliki latar belakang sosial ekonomi yang cenderung lebih tinggi.

Kejadian sindrom metabolik pada penelitian ini hanya muncul pada subyek laki-laki $(21,27 \%)$, sedangkan seluruh subyek perempuan termasuk dalam kelompok pra sindrom metabolik. Hal ini sesuai dengan penelitian yang dilaporkan National Cholesterol Education Program Adult Treatment Panel III (NCEP-ATP III) pada tahun 2000 yang menyebutkan prevalensi laki-laki yang mengalami sindrom metabolik lebih besar dibanding perempuan, yaitu $9,1 \%$ dibanding 3,7 $\% .^{4}$ Penelitian lain pada remaja Cina Indonesia yang obesitas di Jakarta Utara dan Jakarta Selatan mendapatkan prevalensi sindrom metabolik sebesar 19,14\% untuk laki-laki dan 10,63\% untuk perempuan. ${ }^{15}$ Penelitian di Korea tahun 2003 menyebutkan bahwa usia yang dipengaruhi oleh jenis kelamin dapat meningkatkan prevalensi sindrom metabolik, hal ini berhubungan dengan obesitas sentral dan faktor risiko penyakit jantung pada perempuan post menopause. ${ }^{16}$

Berdasarkan kriteria dari NCEP-ATP III, urutan faktor risiko sindrom metabolik pada total subyek penelitian adalah obesitas sentral (100\%), hipokolesterol HDL (90\%), hipertensi (80 \%), hipertrigliseridemia $(60 \%)$, dan terakhir adalah hiperglikemia. Hasil tersebut sejalan dengan penelitian serupa di Brazil yang mendapatkan urutan faktor risiko sindrom metabolik pada remaja adalah obesitas sentral (55\%), kolesterol HDL rendah $(35,5 \%)$, hipertensi (21 \%), hipertrigliseridemia $(18,5 \%)$, dan hiperglikemia (2
\%). ${ }^{17}$ Tingginya kemunculan faktor risiko obesitas sentral pada kedua penelitian menunjukkan bahwa obesitas sentral merupakan faktor risiko utama terjadinya sindrom metabolik pada remaja. Selain itu pada penelitian ini, seluruh subyek mengalami obesitas sentral dikarenakan faktor risiko tersebut dijadikan sebagai faktor skrining dalam menentukan subyek penelitian.

Pada penelitian ini didapatkan nilai median tekanan darah lebih tinggi pada kelompok sindrom metabolik dibandingkan dengan kelompok pra sindrom metabolik. Perubahan nilai-nilai variabel faktor risiko sindrom metabolik pada remaja sangat dipengaruhi oleh asupan makan remaja. Pada masa ini, remaja mulai menentukan sendiri makanan yang disukainya dan sering tanpa memperhitungkan aspek gizi. Pemilihan makan pada remaja merupakan faktor penting yang melatarbelakangi kejadian obesitas remaja selain faktor aktivitas fisik. Remaja kini cenderung memilih makanan dengan ciri tinggi kandungan karbohidrat, tinggi kalori, tinggi lemak dan tinggi natrium. ${ }^{6,} 7$ Asupan yang paling berpengaruh terhadap tekanan darah adalah asupan natrium. Tingginya asupan natrium yang disebabkan oleh pola makan yang salah merupakan faktor risiko hipertensi pada remaja.

Dari hasil penelitian didapatkan asupan natrium memiliki hubungan bermakna dengan tekanan darah sistolik $(\mathrm{p}<0,05)$ dan tekanan darah diastolik $(p<0,01)$. Hal ini sejalan dengan penelitian Luthfiana pada tahun 2012 dimana ditemukan asupan tinggi natrium berisiko 4,536 kali untuk berkembang menjadi hipertensi. ${ }^{18}$ Asupan natrium telah banyak diketahui memiliki hubungan dengan tekanan darah. Asupan natrium yang berlebih menyebabkan retensi natrium di dalam plasma. Retensi natrium menurunkan sintesis nitrit oksida, sebuah vasodilator arteriolar, dan meningkatkan faktor yang menghambat produksi nitrit oksida dalam plasma. ${ }^{19}$ Keseimbangan natrium dalam tubuh diatur oleh aldosteron, sebuah mineralkortikoid yang disekresi adrenal korteks. Ketika kadar natrium dalam darah meningkat, reseptor rasa haus pada hipotalamus menstimulasi sensasi rasa haus. Asupan cairan akan mengembalikan kadar natrium menjadi normal. $^{20}$

Hasil penelitian mendapatkan hubungan antara asupan natrium dan kadar CRP yang tidak bermakna ( $p>0,05)$. Peningkatan kadar CRP muncul sebagai respon proses inflamasi akibat obesitas berkaitan erat dengan peningkatan risiko penyakit kardiovaskuler. Proses inflamasi yang 
ditandai dengan peningkatan kadar CRP merupakan salah satu faktor yang berkaitan dengan kejadian sindrom metabolik. Pada remaja, sindrom metabolik berhubungan dengan peningkatan CRP dibandingkan pada remaja yang tidak mengalami sindrom metabolik. Peningkatan CRP pada masa remaja merupakan prediktor yang menentukan kadar CRP pada masa dewasa dan berhubungan dengan perubahan pada pembuluh darah yang dapat memicu terjadinya aterosklerosis. ${ }^{21}$ Hasil penelitian menunjukkan bahwa subyek penelitian yang memiliki kadar CRP yang tinggi, yaitu $>6$ $\mathrm{mg} / \mathrm{L}$ prevalensinya lebih tinggi terjadi pada subyek perempuan $(53,8 \%)$ dibandingkan dengan subyek laki-laki $(46,2 \%)$.

Hubungan yang tidak bermakna antara asupan natrium dengan kadar CRP $(\mathrm{p}=0,052)$ dikarenakan baik pada subyek dengan kadar CRP tinggi maupun subyek dengan kadar CRP rendah sama-sama mengasup natrium yang lebih dari kebutuhan. Subyek yang mengonsumsi natrium lebih dari kebutuhan yang dianjurkan lebih banyak terdapat pada kelompok dengan kadar CRP rendah yaitu sebesar 55,2 \% sedangkan pada subyek dengan kadar CRP tinggi sebanyak 28,9\% subyek mengasup natrium yang melebihi kebutuhan. Dari hasil wawancara FFQ diketahui sebagian besar subyek yang asupan natriumnya di atas kebutuhan sering mengonsumsi makanan seperti snack-snack gurih, makanan berpengawet seperti sosis dan kornet, mi instan, kecap, kaldu, roti manis, dan sebagainya. Asupan natrium berpengaruh langsung terhadap peningkatan tekanan darah, dimana tekanan darah merupakan faktor risiko sindrom metabolik, namun, asupan natrium mungkin tidak memiliki pengaruh langsung atau berpengaruh sangat kecil terhadap kemunculan reaksi inflamasi di dalam tubuh salah satunya peningkatan kadar CRP.

Tekanan darah sebagai salah satu faktor risiko sindrom metabolik, dalam penelitian ini memiliki hubungan yang tidak bermakna dengan kadar CRP $(p>0,05)$. Sebuah penelitian mengatakan, peningkatan tekanan darah memiliki hubungan kuat dengan kejadian obesitas dan biasa terjadi pada individu dengan resistensi insulin. Hipertensi merupakan salah satu faktor risiko sindrom metabolik, namun, hipertensi memiliki pengaruh kecil terhadap gangguan metabolik dibandingkan dengan komponen sindrom metabolik lainnya. ${ }^{23}$ Selain itu, pengukuran tekanan darah subyek yang tidak merujuk pada pengukuran terstandar mengakibatkan bias pada nilai tekanan darah, dimana bias ini mungkin mempengaruhi hasil perhitungan risiko yang menjadi terlalu kecil memberikan pengaruh terhadap peningkatan CRP.

Faktor lainnya adalah dari berbagai penelitian disebutkan bahwa munculnya biomarker inflamasi seperti CRP disebut-sebut menjadi faktor risiko terjadinya hipertensi yang merupakan awal mula kejadian atherosklerosis. Belum ditemukan penelitian yang menjelaskan mekanisme peningkatan kadar CRP diakibatkan oleh tekanan darah yang meningkat. C-Reactive Protein dilaporkan dapat menurunkan produksi nitrit oksida oleh sel endotelial yang mengawali vasokontriksi, adhesi leukosit, aktivasi platelet, oksidasi, dan trombosis. C-Reactive Protein juga dilaporkan memiliki kemampuan proatherosklerosis dengan meningkatkan regulasi angiotensin tipe 1, yang mempengaruhi sistem renin-angiotensin dan berkontribusi pada kejadian hipertensi. ${ }^{22}$ Tekanan darah merupakan salah satu faktor risiko sindrom metabolik. Dilihat dari nilai RP tekanan darah memiliki risiko sebesar 0,369 kali untuk berkembang menjadi CRP yang tinggi.

\section{SIMPULAN}

Prevalensi sindrom metabolik pada remaja obesitas sebesar 15,2 \%. Asupan natrium yang tinggi memiliki besar risiko 1,031 kali untuk memiliki kadar C-Reactive Protein tinggi pada remaja obesitas sindrom metabolik, dan tekanan darah sistolik yang tinggi memiliki besar risiko 0,369 kali untuk memiliki kadar C-Reactive Protein tinggi pada remaja obesitas sindrom metabolik.

\section{SARAN}

Pemilihan makanan pada remaja hendaknya dilakukan dengan memperhatikan kandungan gizi dalam makanan. Konsumsi natrium per hari perlu dibatasi $2300 \mathrm{mg} / \mathrm{hari}$ untuk mengurangi risiko peningkatan tekanan darah. Selain itu, pencegahan peningkatan kadar $C$ Reactive Protein lebih lanjut dapat dilakukan dengan mengurangi faktor risiko sindrom metabolik salah satunya adalah tekanan darah.

\section{DAFTAR PUSTAKA}

1. Djanggan S, Sri A. The Relationship Between Food Intake and Adolescent Metabolic Syndrome. J Kardiol Indones. 2011;32:14-23.

2. Mohammad SR. Patogenesis dan Terapi Sindroma Metabolik. J Kardiol Ind 2007; 28:160-168.

3. Ram W, James D, Tania SB, William VT, Sara ET, Catherine WY, et al. Obesity and Metabolic 
Syndrome in Children and Adolescents. N Engl J Med 2004;35o:2362-74.

4. Duncan GE, Li SM, Zhou XH. Prevalence and Trends of a Metabolic Syndrome Phenotype Among U.S. Adolescents 1999-2000. Diabetes Care 2004; 27: 2438-2443.

5. Scott MG. Obesity, Metabolic Syndrome, and Cardiovascular Disease. The Journal of Clinical Endocrinology \& Metabolism 89(6):2595-2600, 2004.

6. Alfira D. 2008. Faktor-Faktor Yang Berhubungan Dengan Perilaku Konsumsi Soft Drinks Pada Siswa Smp Negeri 1 Ciputat Tahun 2008. Prodi Kesehatan Masyarakat UIN Syarif Hidayatullah.

7. Faktor-Faktor yang Berhubungan dengan Asupan Kalsium pada Remaja Di Kota Bandung.

8. Oktavia L. Hipertensi Dengan Obesitas: Adakah Peran Endotelin-1?. J Kardiol Ind 2007; 28:460475.

9. Hafifatul AR. 2012. Gambaran konsumsi natrium pada siswa/ima pembangunan UIN Syarif Hidayatullah Jakarta Tahun 2011. Fakultas Kedokteran dan Ilmu Kesehatan UIN Syarif Hidayatullah.

10. Maria IDP. 2010. Korelasi antara GammaGlutamultransferase dengan High-Sensitivity CReactive Protein pada Diabetes Mellitus Tipe 2. Program Studi Patologi Klinik UNS.

11. Sastroasmoro, Sudigdo, Sofyan I. Dasar-dasar Metodologi Penelitian Klinis Edisi ke II. Jakarta:CV Agung Seto, 2002.

12. Faisal, P. Sindroma metabolik dan penyakit kardiovaskular. Divisi Kardiologi Departemen Ilmu Penyakit Dalam Fakultas Kedokteran Universitas Sumatera Utara.

13. Caballero, B. The Global Epidemic of Obesity: An Overview. Epidemiologic Review. Vol. 29, 2007.

14. Mexitalia M, dkk. Sindroma Matabolik Pada Remaja. Media Medika Indonesiana.2009; Vol 43. No 6.

15. Sibarani RP, Rudijanto A, Dekker J, Hiene RJ. The Petai China Study: Metabolic Syndrome Among Obese Indonesian Chinese Adolescents. The Indonesian Journal of Internal Medicine 2006; 38: 142-144.

16. Park S.H., Lee W.Y. \& Kim S.W. (2003a) The Relative Risk of the Metabolic Syndrome Defined by Adult Treatment Pannel 3 According to Insulin Resistance in Korean Population. The Korean Journal of Internal Medicine 64(5), 552-560.

17. Rizzo AC, Goldberg TB, Silva CC, Kurokawa CS, Nunes HR, Corrente JE. Metabolic Syndrome Risk Factors in Overweight, Obes, and Extremely Obese Brazillian Adolescent. Nutrition Journal. 2013;1475-289

18. Fattah, LA. 2012. Asupan Tinggi Natrium dan Berat Badan Lahir sebagai Faktor Risiko Kejadian Hipertensi Obesitas pada Remaja Awal. Prodi Ilmu Gizi Fakultas Kedokteran Undip.
19. Horacio J, Adrogue MD, Nicolaos EM. Sodium and Potassium in the Pathogenesis of Hypertension.

20. L. Kathleen M. Krause's Food and Nutrition Therapy. International edition, 12e. ISBN: 978-08089-2378-7.

21. Deboer MD, Gurka MJ, Sumner AE. Diagnosis of the Metabolic Syndrome is Associated with Disproportionately High Levels of HighSensitivity. An Analysis of NHANES 1999-2008. Diabetes care 34: 734-740, 2011.

22. Howard DS, Julie EB, Nader R, Gavin JB, Michael G, Paul MR. C-Reactive Protein and the Risk of Developing Hypertension. JAMA 2003Vol 290, No. 22.

23. Grundy SM, Brewer HB, Cleeman JJI, Smith SC, Lenfant C, Lenfant JC. Definition of Metabolic Syndrome: Report of the National Heart, Lung, and Blood Institute/American Heart Association Conference on Scientific Issues Related to Definition. Circulation. 2004; 109: 433-438. 